\title{
Calling the World to Come and Share Our Finds: Three Memoirs and Some Highlights from the Founding of Renaissance and Reformation
}

NATALIE ZEMON DAVIS, JAMES MCCONICA, AND GERMAINE WARKENTIN

\section{Natalie Zemon Davis}

Renaissance and Reformation, founded in 1964, grew out of a double wish: a wish for an interdisciplinary scholarly community and a wish for primary sources that could nourish research and teaching when one was far away from the libraries and archives of Europe.

"Renaissance and Reformation" - those words have a familiar ring today, but they inspired novel excitement in 1946-47, when I took a vanguard history course with that title, taught by Leona Gabel at Smith College. Those were the years in which the collaboration between refugees from Hitler's Europe and American scholars was bearing fruit in such works as The Renaissance Philosophy of Man by John Herman Randall and Paul Oskar Kristeller. The art historian Edgar Wind was then at Smith and captivated his listeners with his account, in highly accented English, of Renaissance symbols and mysteries. Leo Spitzer came to lecture on the vernacular and Latin poetry of the Italian Renaissance, and reminded us of the world of Aby Warburg, which he had once known in Hamburg. For us honours students, Wallace Ferguson's The Renaissance in Historical Thought of 1948 was a high point of our historiography seminar.

In the early 1950s, I began my doctoral studies at Harvard and then at the University of Michigan, where my husband had been appointed an instructor in mathematics. To the wide sweep of Renaissance studies, I now added an interest in the new social history; inspired by the rich possibilities of the French archives, I decided to do my dissertation on "Protestantism and the Printing Workers of Lyon." In 1954, the Renaissance Society of America (RSA) was founded; I subscribed eagerly to its periodicals and was thrilled in 1956 when one of my earliest essays - "Holbein's Pictures of Death and the Reformation at Lyons"-was published in Studies in the Renaissance (forerunner of Renaissance Quarterly). 
Such links to an academic community were of great importance to me during those years, for McCarthyite events of the 1950s had uprooted us from the ordinary path of young academics. In 1952, just after my first venture to the French archives, my US passport was confiscated by the Department of State-in part because of my authorship of an (anonymous) pamphlet criticizing the House Committee on Un-American Activities. Two years later my husband was fired from the University of Michigan for his refusal to answer the questions of that House Committee on the grounds of its violation of the first amendment of the Constitution. Relatively isolated from university institutions as I was, membership in the RSA provided a link to the scholarly life I hoped to have. Cut off from the French archives for the foreseeable future, I began to explore the rare book collections in the libraries of New York, where we were then living. My discoveries changed the way I did history from then on: even after my passport was returned in 1960, I combined book history with archival history.

In 1959, I received my doctorate (in absentia) from the University of Michigan and began to teach in the History Department at Brown University. My friendships with literary scholars there, such as the young Miltonist Barbara Lewalski, were as important as those with historians. Harcourt Brown, initially from Toronto, a distinguished scholar of scientific literature and scientific institutions in seventeenth-century France, took the initiative from the French Department to facilitate meetings across the disciplines. The John Carter Brown Library yielded riches in Renaissance travel literature.

In 1962, my husband was awarded a professorship in mathematics at the University of Toronto, and with our young children we became landed immigrants of Canada. Though very happy to be here, I had to find my way again. While regarding Wallace Ferguson at the University of Western Ontario with awe, I knew no one personally in my field when I arrived. For 1963-64, I was able to get a job teaching a humanities course at night at Atkinson College under the inspired leadership of William Kilbourn, and a part-time lectureship in the History Department at the University of Toronto. But much as I enjoyed the teaching, I had no clear institutional base: I was a person on the margins.

But margins are not such a bad place to be. Not long after my arrival, I had the good fortune to meet James McConica, who was himself in a period of transition. He had left behind his teaching in the History Department at the University of Saskatchewan and was studying to be a Basilian priest while 
working towards an MA at the Pontifical Institute for Mediaeval Studies in Toronto. I heard much about his Oxford thesis, which would be published a few years later as English Humanists and Reformation Politics, and told him of my own research in France, which combined social, religious, and cultural history. Jim and I taught together in the humanities course at Atkinson. And from our non-departmental perch, we marvelled at the wealth of talent and expertise in Renaissance and Reformation (including Catholic Reformation) studies distributed across the departments and colleges of the University of Toronto, and beyond at nearby universities. Between us we knew some of these scholars, while others were just names. Why not try to bring people together in an interdisciplinary colloquium, to learn of each other's research and to establish an enduring network of communication in our part of Ontario?

Meanwhile, I had begun to explore the rare book collections in Toronto, starting with the Rare Book Room under Marion Brown's curatorship at the old University Library. My book-finding muscles from New York days were still in good order. I began with the J. Stanley Will collection, purchased by the University Library in 1961-62 from a retired professor of French. It included some 380 books in French history and literature published before 1700; they were useful for me, but I was sure they would be of importance for others as well. When some older colleagues expressed doubt about the richness of local holdings, I countered that hidden treasures were going to appear. Indeed, at that very moment, F. David Hoeniger had been appointed by the Board of Regents of Victoria College to plan a Centre for Reformation and Renaissance Studies (CRRS) at Victoria College. It would be built, to start, around Victoria's Bell Collection, comprising many more editions of Erasmus than anyone knew were available in Toronto.

Jim and I surely planned the early meetings of the Toronto Renaissance and Reformation Colloquium (TRRC) together. I don't recall how far we got in thinking about the bulletin Renaissance and Reformation. Jim was going to be away on his novitiate in the Basilian order during 1964-65, and the three issues during that first academic year were all edited by me. Perhaps I conceived it on my own, and expected that Jim would join me upon his return in 1965, as indeed he did. In any case, for the first issues, I sought brief articles or announcements from colleagues, and wrote the rest myself. I typed up the stencils, ran them off on a mimeograph machine (perhaps the one belonging to the Department of Political Economy, where I had just obtained a post teaching 
economic history), and mailed them out free of charge to colleagues in Toronto and nearby. (Once Germaine Warkentin joined us as editorial assistant in 1966, all this became much more efficient and elegant.)

Useful models were Renaissance News, a bulletin of news, short research articles, and bibliography, which pre-dated the formation of the RSA and was then taken over by the RSA as a periodical; and the History of Ideas Newsletter. The latter had been founded in 1954 by Barnard College's Rosalie Colie, whom I had got to know and admire in 1956 when I taught a night-school course at the Columbia School of General Studies. As initially conceived, Renaissance and Reformation would have news of events and persons; but rather than short essays reporting the results of research, the articles would describe local collections so as to enable research-including research in new directions. ${ }^{1}$ Thus, the opening issue in October 1964 announced the formation of the TRRC and the plan to establish the CRRS at Victoria, and described sixteenth-century holdings in the Trinity College Library. Renaissance and Reformation was an attempt to create a community and help it discover its resources.

\section{James McConica, c.s.b.}

$I^{t}$ was this local initiative that really confirmed my arrival at the University of Toronto. I came to the St. George campus in 1964, but not strictly to the university: it was in St. Basil's Seminary at 95 St. Joseph Street where, following two years of medieval philosophy at the university and a novitiate year, I began four years of theology preparatory to ordination to the priesthood with the Basilian Fathers, founders of St. Michael's College. That prospect was still something of a surprise to myself.

In 1963, I had completed a DPhil at Oxford under the direction of then Regius Professor of Modern History Hugh Trevor Roper. The topic was "The Continuity of Humanist Ideas during the English Reformation.” I was entirely unprepared for what awaited me in my research: the pervasive presence among the English opinion-formers of Christian humanists, most notably Desiderius Erasmus, a figure I had to that point rather dismissed as a marginal influence. I

1. Though the journal long ago began offering research articles as its primary contribution to the scholarly community, this special anniversary issue in fact hearkens back to Renaissance and Reformation's origins as "resource-finder" by including essays on three of the rich early modern library holdings available in Canada. See the final section of this issue. 
found myself now entirely engaged in the "Northern Renaissance." At the same time, I resigned my position at the University of Saskatchewan to explore the possibility of a priestly vocation. As I was determined to combine with this new direction my existing commitment to academe, I had to think carefully about the direction of my ministry. I had no disposition to join a religious community, so after a brief canvass of opinion, I applied to the Archdiocese of Montréal. The reasons were two-fold. Prior to my reception into the Church in 1958, the substantial part of my reading in Catholic literature and theology had been in French, during the efflorescence of the French Church in the years immediately after the war: Mauriac, Claudel, Gabriel Marcel, Gilson, Congar, de Lubac, and so forth. The second consideration was that after my three undergraduate years in Oxford, I wanted emphatically to repatriate as a Canadian.

A short and daunting interview with Cardinal Emile Léger led to my concerns being taken in hand by the Chancellor of the Archdiocese, who proved very congenial. He effectively promised to arrange for me to study theology wherever I wished, an offer that immediately raised the question of reclaiming my Canadian identity. Noting that my double honours course at Saskatchewan in history and philosophy had included no medieval philosophy, he proposed that I enrol for an MA in medieval philosophy with instruction at the Pontifical Institute of Mediaeval Studies (PIMS) in Toronto. I was not slow to accept such a seductive proposal, and so it was that I first arrived at 95 St. Joseph Street, not as a Basilian postulant but as a diocesan candidate for Montréal. In the course of the next two years I had the privilege of seminars with some of the most eminent men in the field: Armand Maurer (Scotus and Ockham); Ignatius Eschman (Prudentia in Aquinas compared with phronesis in the Nichomachean Ethics Book II); and Joseph Owens (metaphysics in Aquinas). It was with Owens that I chose to write my MA thesis. My topic, proposed by Owens, was rebarbative on the surface, but it proved to be a superb instrument for someone in transition from a secular and post-Protestant culture to Catholic theology: "St. Thomas Aquinas's Doctrine of Analogy 'per posterius' and 'by participation' in the Commentary on the Sentences."

By this time I realized that I had found my new home, with priests who were scholars and teachers, and who were doing exactly what I hoped to do. At the conclusion of my second year I received my MA from the University of Toronto, and applied to enter the Basilian novitiate. Unknown to me, a Delegate of the Press in Oxford had recommended my thesis for publication, with the 
result that amid my final MA year came the scramble to revise the thesis for publication. I did so rather hastily, spending the following summer in Oxford, and in the novitiate year that autumn and winter I proofread the index of my published thesis-English Humanists and Reformation Politics-in the bucolic tranquillity of the Basilian novitiate located then at Erindale, which is today on the Mississauga campus.

As yet I knew no one in the University of Toronto, but fortuitously had met Natalie Zemon Davis at a regional meeting of the RSA held at the University of Western Ontario in the summer of 1963. It was clear from the outset that our interests converged. Those interests might most simply be described as intellectual and cultural history in sixteenth-century Europe-hers in France, and mine in England. Auspiciously, the regional meeting of the RSA had been located at Western to mark the return to Canada of one of its founders, Wallace K. Ferguson, whose eminence in the field of Renaissance intellectual history was shortly to lend great impetus and needed credibility to a remarkable venture of the University of Toronto Press: the Englishing of the Opera omnia of Erasmus of Rotterdam. At that moment, this gave me personal reassurance about the unknown future of my own historical interests in Canada and, more especially, in Ontario.

The reader will now be aware of the striking convergence of my path with that of Natalie. A marginal person in the Toronto community myself, I benefitted greatly from a generous invitation to participate with her in William Kilbourn's course at Atkinson College-where I forbore to wear my scholastic's cassock in the classroom. My doctoral investigations in England, in which I sought to situate the "received" Reformation story in the context of shifting lay culture and the impact upon it of the printing press, led me as well into the varied deposits of early printed books on campus, where the Bell Collection of books by Erasmus at Victoria College was particularly welcome. Natalie has herein described quite perfectly our shared sense of the potential for creative development right on our doorstep in Toronto where, night after night, one could see the human side of the equation: ambitious Torontonians in their striving years, many of them newcomers to Canada, all eager to improve their standing and willing to make the sacrifices needed to do so.

In the course of my years in theology I came to know the library holdings on the St. George campus much better. Apart from the extensive holdings at St. Michael's College and the remarkable resources of the library at PIMS, there 
were rich complementary resources at the three colleges-Trinity, Victoria, and Knox - that shared a founding history of confessional allegiance. Apparent also was the coming-together of Toronto scholars from various departmentsEnglish, French, and Italian, as well as History and Political Economy-who were all focused on what came eventually to be called the "early modern period." The first enduring expression of that reality was the Toronto Renaissance and Reformation Colloquium (TRRC), a joint initiative of myself with Natalie, who was certainly the moving spirit and who has described elsewhere its advent and aims. ${ }^{2}$ It is perhaps also worth recalling a constellation of events around the TRRC. First were the invaluable initiatives at Victoria College that brought the Centre for Reformation and Renaissance Studies (CRRS) into existence, the slightly modified title reflecting deference to Emmanuel College's tradition and library holdings. Shortly afterwards, following the initiative of one of its editors, Ron Schoeffel, the University of Toronto Press embarked on its signal enterprise, the Collected Works of Erasmus, whose expanding archive of important photostats and Xeroxes was stored cumulatively at the CRRS in quiet acknowledgement of the Centre's advent on campus. By 1974, the press was publishing the Erasmus Newsletter, another organ of communication and one which, albeit with a more focused public, owed an evident debt to Renaissance and Reformation.

Upon my ordination in the Basilian community I was appointed to the Pontifical Institute. My purpose now was to enlarge my knowledge of "northern humanism" and particularly the place in it of Erasmus. The president of PIMS, Father Shook, who was a Harvard-trained Anglo-Saxonist and a man capable of looking very stern, asked me: "Was Erasmus medieval?" I replied firmly but uneasily that he was probably born in the late 1460s, that he was a disciple in the next generation of Lorenzo Valla, and that he represented the continuing vitality of the medieval humanism about which Richard Southern had written so effectively. I left the interview with a sense that my leg had been quite firmly and definitively pulled.

Benign as my colleagues at PIMS proved to be, I needed contacts and conversations among colleagues in the broad stream of Renaissance studies. For this the Colloquium and its periodical were not only ideal, but essential.

2. On the TRRC's evolution as an organization from its origins to the present day, see the contribution by Elizabeth S. Cohen and Jane Couchman entitled "The Toronto Renaissance and Reformation Colloquium: An Independent Intellectual Forum at Fifty Years," in issue 37.4 of this journal (forthcoming). 
Our search through the local college libraries for early printed books, for example, was an initiative derived from the TRRC, and out of it came an article, “Tudor Translations of Continental Reformers in Toronto Libraries," which I published in Renaissance and Reformation (2.1) in January 1966. The remarkable and revelatory finding-list of legal works, with Natalie Davis and Richard Schoeck, was a more ambitious example of what it seemed that the Colloquium would stand for: the opening of doors to a community of scholars whose members had hitherto been defined and to some degree separated by departmental allegiances. That publication, too, appeared in Renaissance and Reformation (volume 4, 1967-68).

In the twilight of the '60s, I was invited to take responsibility for the third volume of the newly-commissioned History of the University of Oxford, and I left PIMS for Oxford in 1969, with an abiding sense of gratitude for my unforeseen and unforeseeable introduction to Toronto.

\section{Germaine Warkentin}

$I^{\prime}$ was 1963 when my husband and I returned to Toronto after six years in Winnipeg, where he had taught geography, our daughter was born, and I discovered Renaissance English literature. My BA (Toronto ) was in honours philosophy, but United College in Winnipeg had needed term-contract faculty, and was I reported to have read a book or two, so there I was in front of a class, Shakespeare in hand. Now, in a suburban Toronto townhouse, what was I to do? Go back to school, of course! Fortunately I didn't realize until later that in the early '60s returning to school was a very unusual thing for a young professor's wife to do. Entering the daunting Toronto PhD programme in English, I found not only that I had to take make-up courses (it wasn't enough to have read a book or two) but that I was ten years older than my fellow students, none of whom had four-year-olds at home or husbands with demanding new jobs. The years from 1964 to 1968 were tough, but a blooming new initiative driven by two other Toronto newcomers made all the difference.

Natalie Zemon Davis and James McConica, both historians, had arrived in Toronto about the same time as I returned and, like me, they didn't fit the accepted pattern for the academy, as you can see from their contributions to this three-way memoir. Furthermore, unlike myself they were both entirely new to Toronto. But first Natalie and then Jim set about to find out what interesting 
people and good intellectual resources there were to further their work in the early modern period. Faculty at the University of Toronto had always stayed within their disciplinary boundaries, but in a couple of years Natalie put together a list of over a hundred people who were teaching in the period, a list that drove right through all those boundaries. And she and Jim proceeded to bring our colleagues together to talk to each other. It was a remarkable moment: people who had never met except in the then-infrequent Faculty of Arts committees, or in their own colleges, could begin to see what their colleagues elsewhere were doing, and share their own work. And they did. Within weeks, Renaissance and Reformation began as the news bulletin of the new initiative, and the Toronto Renaissance and Reformation Colloquium started regular meetings. And, as noted above, it was precisely then that the Centre for Reformation and Renaissance Studies was being founded by F. David Hoeniger at Victoria College. Suddenly, a group of people who hardly knew more than each others' names possessed a nascent journal, a society, and a research library, all independently organized but ready to collaborate.

If the years 1964-68 were tough for me as a student who didn't fit in, they were wonderful in another way, because when I discovered the Renaissance and Reformation newsletter and found out what was going on, I plunged right in to help. As a mere graduate student I had nothing yet to share with Natalie and Jim academically, but during my decade more or less out of school I had been very active in the film society movement in Toronto and Winnipeg as editor of their bulletin, Canadian Newsreel, and nationally as chair of the Canadian Federation of Film Societies. My administrative and editorial skills were humble, but they were available. Very soon I became secretary of the TRRC and editorial assistant for Renaissance and Reformation. My fellow students stayed close to their books, but I was in a position to meet everyone on campus who was interested in my field, and though I did not neglect my studies, I was learning every day from these new colleagues.

The most important thing I learned came from their intense interest in primary materials. We were used to thinking that to do that kind of research you had to go away: to the British Museum as it then was, to the Bibliothèque Nationale, to Oxford, Basel, Florence. And in those days few of us could afford to go away. Natalie pointed to another direction by asking what rare books and early papers were to be found in southern Ontario and nearby upstate New York. The libraries she and Jim contacted began to reveal their riches, which were 
sometimes modest but always genuine. Renaissance and Reformation reported on forgotten university collections and private libraries long neglected-books that were right under our noses. The project I remember most clearly was the great legal bibliography we published in volume 4 (1967-68). This project was facilitated by Professor Richard Schoeck's expertise, and it drew on libraries of early law books both local and elsewhere in eastern Canada. My job was to type this manuscript, and as I did so, I began to learn not only about law books, but about a way of thinking about books that was new to me.

Today, most of my work is as a book historian, and this is because, in those early years, work on Renaissance and Reformation taught me about how early books were made and circulated, about collectors and libraries, and about the fate of early publications in the hands of later users, one of whom was me. I began to haunt any early collections I could find, including what came to be called the Thomas Fisher Rare Book Library, just then being assembled on the basis of the university's earlier, little-known collections. My first academic paper, "Some Renaissance Schoolbooks in the Osborne Collection," was published in Renaissance and Reformation in 1969. When I began to teach in 1970 I made sure to introduce my students to the riches of the local collections; students of Renaissance poetry already had much to explore at Fisher, but so did my students of Canadian literature, whom I regularly sent to look at writers' papers and early little magazines.

In the intervening period, I have served for five years as Director of CRRS, and served a stint (my second) as chair of TRRC from 2011 to 2013; in 2011 my York colleague Thomas V. Cohen and I guest-edited a special issue of Renaissance and Reformation entitled Things Not Easily Believed: Introducing the Early Modern Relation. My own work in book history has branched out into a project studying the ways homo sapiens sapiens began to invent the book by making marks on the material objects available to them. That, of course, all happened very long ago compared with the fifty years in which Renaissance and Reformation was founded and has thrived. The latter, for Natalie, Jim, and myself, has seemed like no time at all. 


\section{Highlights of the First Five Years of Renaissance and Reformation Compiled by Natalie Zemon Davis}

$R_{\text {enaissance and Reformation: A Bulletin for Scholars in the Toronto Area was }}$ times a year in mimeographed form. The first number of October 1964 was three pages long and went to some forty people; in May 1969, the forty-page publication (and some issues were much longer) had three hundred readers and was received by twenty-five libraries in Canada and beyond. Though Renaissance and Reformation remained a labour of love for the editorial team, subscriptions were eventually included in the modest membership fees of the Toronto Renaissance and Reformation Colloquium.

Renaissance and Reformation continued to bring news to readers over the years, announcing Toronto lectures in many disciplines, musical and theatrical events, and regional Renaissance conferences. F. David Hoeniger's annual reports on the Centre for Reformation and Renaissance Studies bear witness to the remarkable growth of its library and activities. In April 1968 (4.3), he described the Centre's recent well-attended lectures by Roland Bainton, the great Luther and Erasmus specialist from Yale: "Erasmus and the Liberal Catholic Reform" and "Erasmus and the Protestant Reform." The Centre now had six thousand volumes in its library with plans for many more acquisitions, and it had invited graduate students to serve as Fellows. That year, the CRRS Fellows were Germaine Warkentin and Jane Couchman, who were to go on to make outstanding contributions to Renaissance scholarship.

Other colleagues reported news from near and far. Victor Graham gave an account of the 1965 annual meeting of the Renaissance Society of America in New York; Paul Grendler told of the reopening of the Biblioteca Nazionale Centrale in Florence, at which he had been present in January 1968, and described what had been restored and what remained to be done in the wake of the 1966 flood. (Renaissance and Reformation had urged readers to contribute to the restoration expenses.) In February 1969, in the periodical's first article written in French, J. M. de Bujanda announced the recent establishment of the Centre détudes de la Renaissance at the Université de Sherbrooke. ${ }^{3}$

3. For more information on the Centre d'études and an account of one of its projects, see the article by J. M. de Bujanda entitled "Travaux sur la censure et les index des livres interdits réalisés à l'Université de Sherbrooke," in issue 37.4 of this journal (forthcoming). 
The main work of Renaissance and Reformation during those first years was to publish finding-lists of books and reports of library holdings and collections. As it turned out, these essays became entries into whole new fields of study as well as contributions to the history of the book. Beatrice Corrigan's "Census of Emblem Books in Toronto" (2.3 and 3.1) described over a hundred individual editions of this popular genre, printed from the sixteenth to the nineteenth century. (Sibille Pantazzi added a list of emblem books existing only in facsimile in Toronto collections.) Combining motto or adage with associated image and verse, in Latin and in vernaculars, emblem books had multiple uses.

Among the late titles on Corrigan's census were some emblem books intended for the moral instruction of children. As she mentions above, Germaine devoted a whole article (5.3) to "Some Renaissance Schoolbooks in the Osborne Collection" (then housed at the Boys and Girls Library, the Osborne Collection is today located at the Lillian Smith Branch of the Toronto Public Library). After describing the range of books published for the young in the collection, Warkentin gave bibliographical description to and some illustrated pages from individual books that could have been used for the education of young gentlemen. These included instruction in grammar, arithmetic, and especially morality.

A very different kind of instructional text was presented by Maria Rika Maniates in her "Musical Treatises of the Renaissance" (3.2). Written by musicians for musicians, these books "are concerned mainly with rules of theory and composition, or description of instruments and performance practice." Maniates listed the numerous editions at the Music Library, many of them facsimiles of the originals from the sixteenth and seventeenth centuries, and described them and their authors sufficiently so as to introduce the reader to central features and quarrels of Renaissance and Baroque musical life.

Several articles address the history of science, medicine, and technology during the Renaissance, subjects given scant attention in the teaching programs in Toronto in the early 1960s. In early issues $(1.3,2.2)$, Natalie Zemon Davis described holdings on sixteenth- and seventeenth-century midwifery and pediatrics - both printed books and manuscripts - which were then part of the T. G. H. Drake collection at the Toronto Academy of Medicine Library. (The academy donated these books to the Thomas Fisher Library in 1991.) Andrew Watson introduced readers to the variety of early printed books on 
farming and husbandry, both classical and newly composed, which could be found at the University Library (1.3). Hoeniger and Joel Kaplan filled in the picture with a wider survey of zoological and botanical editions, 14501700, in several Toronto libraries and in the possession of Hoeniger himself (3.3). Then, in January 1968 (3.2), readers of Renaissance and Reformation received a first notice of the extraordinary collection of books in the history of early modern science and mathematics assembled by Stillman Drake. Drake himself gave an overview of the collection, which he had housed at the Rare Books Library at the University of Toronto so that it could be available to scholars (he would eventually donate it fully to the library). Those interested, Drake added, could contact him "at the newly-created Institute for the History and Philosophy of Science and Technology." The articles in Renaissance and Reformation were thus part of the local ferment which led to the new Institute.

In a sense, all the surveys and censuses in the bulletin contained information useful for the history of the book, but some explorations offered direct paths into the mentality of printers, book-buyers, or collectors of the sixteenth and seventeenth centuries. Such were the review of "Pamphlets and Propaganda in the Italian Wars, 1494-1512" by Cecil H. Clough (3.3) and "A Checklist of French Political and Religious Pamphlets, 1560-1653, in the University of Toronto Library" by Natalie Zemon Davis and John A. McClelland (5.3). The pamphlet titles themselves indicated the character and presentation of "news" during the Renaissance, Reformation, and afterward; the information about the printers or the concealment of the printer's name and place of publication told stories about the relation of the pamphlet to political and religious authority. Similarly, James McConica's article on "Tudor Translations of Continental Reformers in Toronto Libraries" (2.2) gave evidence for the role of printers, Puritan translators, and patrons in the transfer of religious ideas across the Channel. The movement of books was also the theme of Natalie's review of "Sixteenth-Century Continental Editions and Authors in the Forbes Collection" (5.1). James Forbes was a seventeenthcentury non-conformist minister in Gloucester, England, and Natalie's report of earlier signatures in some thirty-five editions attested to the changing ownership of books and their cost. 
The University of Toronto had acquired Forbes's collection in 1966: some 1,800 books and manuscripts from the sixteenth and seventeenth centuries. In several articles (5.1-3), Michael Finlayson and David Sinclair showed in rich detail how a library collection could speak to the mental universe of its owner, a staunch Independent, and to the practices of book-collecting.

Perhaps the most ambitious undertaking of the first five years of Renaissance and Reformation was the "Finding-List of Renaissance Legal Works to 1700," directed by Richard J. Schoeck and carried out by him, Natalie, and Jim, with the assistance of William Dean (4.1-3). Dick did not limit their search to Toronto libraries: they were in touch with libraries in Ottawa, Montréal, Kingston, and other parts of Canada. (When they missed the Laurentian University Library, Robert Toupin sent valuable addenda [5.2].) Organized by categories-Roman civil law; canon law; English common law; national and customary law of France, Germany, and elsewhere; and comparative law-the "Finding-List" was replete with introductions, biographies of legal authors and jurists, and bibliographical detail. As such, it served as an introduction to the legal history of the early modern period and the role of publication in the dissemination and transformation of legal systems.

Not surprisingly, a mimeographed bulletin, held together by a staple in one corner, began to seem an inappropriate format for Renaissance and Reformation, even when reference to its pages had been much eased by indexes prepared by Germaine. In the spring of 1969 (5.3), the editors announced that henceforth Renaissance and Reformation would be printed by the University of Toronto Press. A new team would edit the periodical. Initially it was thought the concentration on "resources for research" would continue, but eventually the journal was to develop in exciting new directions as Renaissance and Reformation/Renaissance et Réforme.

In 2003, at a small gathering at which Germaine and Jim were present for Natalie's seventy-fifth birthday, her husband, Chandler Davis, read aloud a sonnet he had written to catch the spirit of their earlier enterprise: 


\section{Treasure Hunters}

From Academy of Medicine in the west

To St. Mike's on the east, from Vic to Knox,

What Renaissance wealth our libraries possessed!

Like mineralogists assaying rocks,

Assyriologists sifting desert tells,

Or Egyptologists exhuming crypts,

You hunted treasures on the library shelves,

Their incunabula and manuscripts.

So many you found so fast, there was no way

Your students' research papers and your own

Could give them proper framing straight away, And yet you couldn't wait to make them known;

So, shouting Eureka! to the Toronto winds,

You called the world to come and share your finds. 


\title{
西
}

\author{
anth
}

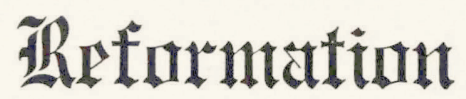

Volume VI (1969-70)

Number 1 
Renaissance and Reformation is published three times yearly (September-June) by the University of Toronto Renaissance and Reformation Colloquium and by the Victoria University Centre for Renaissance and Reformation Studies.

\section{Editors (1969-70)}

John McClelland James M. Estes

\section{Editorial Committee}

F. David Hoeniger (Chairman)

Beatrice Corrigan

Natalie Davis

Thomas Cain

Brayton Polka

Subscription price: $\$ 2.50$ (Can.) per year. All enquiries, subscriptions, and manuscripts should be addressed to:

The Editor,

Renaissance and Reformation

CRRS, Victoria University,

Toronto 5, Canada.

All back issues are available, at a cost of $\$ 1.00$ per number or $\$ 2.50$ per volume. 


\section{CONTENTS}

Editors' Foreword $\ldots \ldots \ldots \ldots \ldots \ldots \ldots \ldots \ldots \ldots \ldots \ldots, 4$

Announcements $\ldots \ldots \ldots \ldots \ldots \ldots \ldots \ldots \ldots \ldots \ldots \ldots \ldots \ldots \ldots, \quad 4$

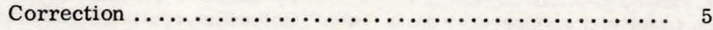

Communications $\ldots \ldots \ldots \ldots \ldots \ldots \ldots \ldots \ldots \ldots \ldots \ldots \ldots \ldots \ldots$

Corpus Reformatorum Italicorum.

By Anne Jacobson Shutte ................... 6

Sixteenth and Seventeenth Century France in Saskatchewan.

By J. Michael Hayden ..................... 8 